Edukids volume 15 (2) tahun 2018

EDUKIDS: Jurnal Pertumbuhan, Perkembangan, dan Pendidikan Anak Usia Dini

Jln. Dr. Setiabudhi No. 229 Kota Bandung 40154. e-mail: edukid@ upi.edu website: http://ejournal.upi.edu/index.php/edukid

\title{
UPAYA GURU DALAM MENANAMKAN SIFAT SABAR DI RA PERSIS I KOTA BANDUNG
}

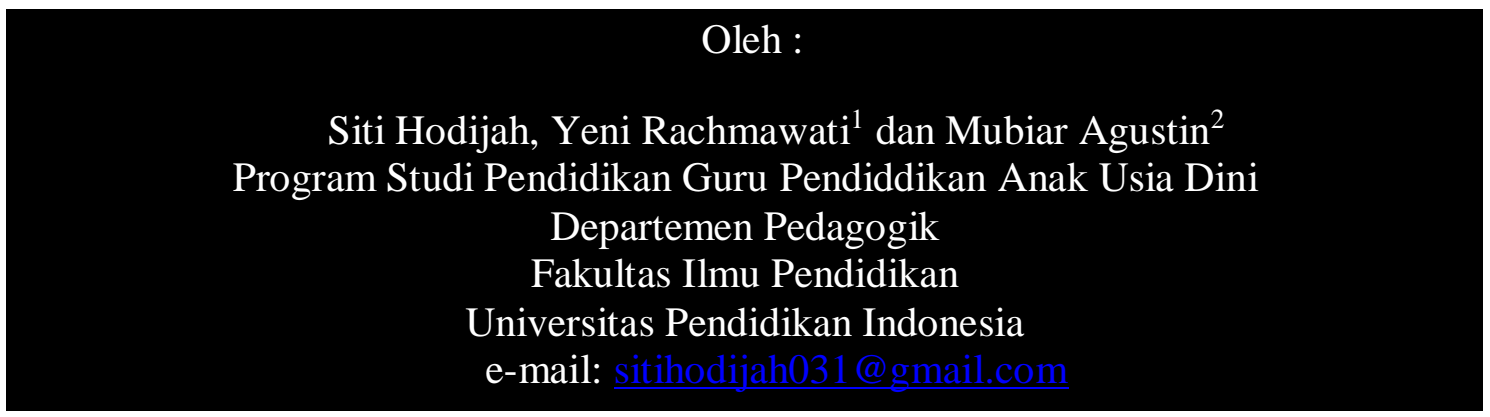

\begin{abstract}
Abstrak: Penelitian ini dilatarbelakangi oleh situasi di lapangan, dimana ditemukan guru yang kurang tanggap ketika ada anak yang berkata kasar, merebut mainan temannya, pemarah, tidak sabar ketika menginginkan sesuatu, tidak sabar mengantri dalam melakukan kegiatan dan bermain, tidak sabar ketika menyelesaikan tugasnya, tidak mencuci tangan saat makan, dan suka mengganggu temannya ketika belajar dan bermain. Perilaku tersebut terus menerus dilakukan sehingga menjadi kebiasaan dan mengakibatkan perilaku tidak baik. Selain itu, dapat menjadi permasalahan ketika anak dewasa kelak. Dari permasalahan ini peneliti tertarik untuk mengungkap upaya guru dalam menanamkan sifat sabar pada anak usia dini. Tujuan penelitian ini adalah untuk mengetahui lebih dalam mengenai upaya guru dalam menanamkan sifat sabar pada anak usia dini. Peneliti bertindak langsung sebagai instrumen. Data dikumpulkan melalui observasi, wawancara dan dokumentasi. Sedangkan metode penelitian ini yaitu metode penelitian studi kasus dengan pendekatan kualitatif. Hasil temuan penelitian menunjukkan bahwa untuk menanamkan sifat sabar dalam pelaksananaannya dapat menggunakan metode dengan cara keteladanan, pembiasaan, nasihat, dan cerita. Adapun bentuk-bentuk perilaku akhlakul karimah yang dapat diajarkan diantaranya mengucapkan salam, meminta maaf jika melakukan kesalahan, mengaji iqro, membaca do'a sehari-hari, membaca surat-surat pendek, membaca mahfudzat (kata mutiara dalam bahasa arab), praktek wudhu dan praktek shalat. Selain itu terdapat penanaman guru terhadap anak untuk berlaku sabar, diantaranya sabar mengantri dan sabar menunggu giliran. Adapun hambatan yang dihadapi guru dalam menanamkan sifat sabar pada anak yaitu terdapat emosi anak yang belum stabil. Sementara itu cara pencegahan serta solusi untuk anak yang tidak bisa bersabar diantaranya yaitu dengan memeluk anak, memberikan pengertian, dan mengenal karakter anak.
\end{abstract}

\section{Kata kunci: upaya guru, sifat sabar, pencegahan, solusi}

Abstract: Background of this research is gotten from field situation where teacher is discovered as lack of responsive when students spoke in rude words, seize their toy's friend rudely, grumpy, not patient when students want something, not patient when students have to make a line to wait for their turn in activities and playing, not patient in doing their assignment, not washing their hands before meal time, and often disturbed their friends when study time and play time. Those attitudes are kept be done till finally it becomes behavior and causes bad attitudes. Beside, those can be problems when children 
grow up. From the problems that gained in the field, researchers are interested to expose teacher's effort in implanting akhlakul karimah to children especially in patient characters. The intention of this research is to know deeper about teacher's effort in implanting akhlakul karimah to children especially in patient characters. While, method research that being used is case study research method with qualitative approach where case study investigation is studying deeper about agency organization or certain social symptoms. Researcher acts directly as instrument. Data are collected through observation, interview, and documentation. The result found by researcher is showing that to implant akhlakul karimah in the implementation, teacher may use method by using exemplary, habituation, advice speech, and storytelling. Patient Character that can be taught by teachers are greeting, apologizing if doing something wrong, iqro' reading, praying of daily du'a, reading short surahs, reading mahfudzat (quotes in Arabic), wudhu practices and pray practices. Patient characters implanting by teachers can be done through patient in queueing and patient in waiting turn. The obstacles faced by teachers in instilling impatience in children is that there are emotions that are not yet stable children. Meanwhile, prevention and solution of impatient children are embrace them, give them understanding feeling, know their characters.

\section{Keywords: teacher's effort, patient character, prevention, solution}

\section{PENDAHULUAN}

Anak merupakan generasi penerus bangsa. Oleh karena itu, mereka haruslah mendapat perhatian dan pendidikan yang serius, sebab pada masa inilah belajar itu dimulai. Baik tidaknya moral anak berawal dari sini, apabila pendidikan akhlak atau moral itu diberikan sejak kecil maka anak akan terbiasa bersikap baik, begitu pula sebaliknya. Hal ini sebaiknya dilakukan sejak usia dini. Seperti yang kita ketahui bahwa masa anak merupakan fase yang sangat fundamental bagi perkembangan individu, karena pada fase inilah terjadinya peluang yang sangat besar untuk pembentukan dan pengembangan pribadi seseorang (Syaodih, t.t). Mengingat pentingnya pendidikan bagi perkembangan kecerdasan moral anak usia dini, maka penting bagi orang tua untuk memberikan kesempatan pada anak-anak dan membantu proses perkembangan, diantaranya memilih lembaga pendidikan (Taman Kanakkanak) yang tepat artinya strategi dan metode pengajaran yang digunakan perlu disesuaikan dengan karakteristik yang dimiliki oleh anak-anak (Sari, 2010).
Lembaga pendidikan memegang peranan yang tidak kalah penting bagi tercapainya peletakan dasar atau berawalnya pendidikan bagi anak usia dini. Salah satu tugas lembaga pendidikan harus bisa menyeimbangkan antara pendidikan akhlak bagi anak usia dini dan kebebasan anak dalam mengembangkan fantasinya. Fachruddin (1985, hlm.1), mengungkapkan bahwa, "Apabila generasi yang akan datang lebih buruk dari angkatan yang sekarang, sesungguhnya merupakan suatu kerugian yang sangat besar dan kemunduran".

Adapun terjemahan ayat Al-Qur'an mengenai hal tersebut, yaitu Q.S An-Nisa (4:9) yang berbunyi:

"Dan hendaklah takut kepada Allah orang-orang yang seandainya meninggalkan dibelakang mereka anak-anak yang lemah, yang mereka khawatirkan terhadap (kesejahteraan) mereka. Oleh sebab itu hendaklah mereka bertakwa kepada Allah dan hendaklah mereka 
mengucapkan perkataan yang benar"

Untuk pencapaian tujuan yang mulia, maka tidak menutup kemungkinan peran seorang pendidik dalam mempengaruhi anak agar mempunyai akhlak yang mulia (karimah). Sejalan dengan pendapat tersebut, maka Danim (2011, hlm. 5) mengungkapkan bahwa, "Guru adalah pendidik, yang menjadi tokoh, panutan, dan identifikasi bagi para peserta didik, dan lingkungannya".

Pada kenyataannya, banyak sekali kendala dalam menanamkan akhlakul karimah terhadap anak. Komisi Perlindungan Anak Indonesia (KPAI) mencatat pengaduan terkait dengan persoalan anak sebanyak 3.849 kasus pada tahun 2017. Hal ini mengenai kasus video pornografi yang korbannya lebih dari 750.000 anak, serta kasus-kasus perundungan (bullying) yang masih terjadi di sekolah-sekolah di Tanah Air. Pada tahun 2017, anak laki-laki sebanyak 1.234 atau 54 persen dan anak perempuan sebanyak $1064 \quad$ (46 persen) sebagai korban dan pelaku. Sedangkan kasus anak yang berhadapan dengan hukum $(\mathrm{ABH})$ masih menjadi kasus tertinggi di KPAI dengan kasus sebanyak 1.209 kasus, diantaranya ada anak sebagai pelaku kekerasan dan anak sebagai korban. Dari data tersebut, KPAI berpandangan bahwa kerentanan anak saat ini tidak lagi hanya menjadi korban, tetapi menjadi pelaku tersebut juga merupakan "korban" dari persoalan pengasuhan di keluarga maupun situasi lingkungan yang kurang mendukung. (KPAI, 2017)

Hal ini tentu akan berdampak bagi perkembangan moral anak, yang akan berdampak pada masa depannya. Sejalan dengan ungkapan Hainstok (1999, hlm.16) bahwa,
"Banyak orang tua kurang memiliki kesadaran untuk memperhatikan setiap perkembangan seorang anak sehingga mempengaruhi pola pendidikan yang diberikan kepada anak tersebut".

Berdasarkan observasi awal, ada diantara guru yang kurang tanggap ketika ada anak yang berkata kasar, merebut mainan temannya, pemarah, tidak sabar ketika menginginkan sesuatu, tidak sabar mengantri dalam melakukan kegiatan dan bermain, tidak sabar ketika menyelesaikan tugasnya dan mencuci tangan, suka mengganggu temannya ketika belajar dan bermain. Perilaku tersebut terus menerus dilakukan sehingga menjadi kebiasaan dan mengakibatkan perilaku tidak baik, serta akan menjadi permasalahan ketika anak dewasa kelak

Berkenaan dengan hal tersebut, maka sebagai seorang guru mempunyai peran dalam membangun mental anak untuk berperilaku sopan, santun, dan berakhlakul karimah. Proses pelatihan akhlakul karimah harus dilakukan semenjak anak-anak, sehingga setelah dewasa nanti tidak menjadi hambatan dan berperilaku akhlakul karimah. Sebab apabila sudah terbiasa baik akan terbiasa berperilaku akhlakul karimah. Begitupun sebaliknya, apabila tidak membiasakan dirinya berperilaku akhlakul karimah pada akhirnya akan sulit dalam melakukan hal kebaikan.

Berdasarkan latar belakang yang telah diuraikan, maka penelitian memfokuskan kajian penelitian tentang upaya guru dalam menanamkan sifat sabar pada anak usia dini di RA Persis I. Adapun rumusan masalah dalam penelitian ini dijabarkan dalam pertanyaan sebagai berikut: 
1. Bagaimana upaya guru dalam menanamkan sifat sabar pada anak usia dini di RA Persis I ?

2. Apa sajakah hambatan yang di hadapi guru dalam menanamkan sifat sabar pada anak usia dini di RA Persis I ?

3. Bagaimanakah solusi guru untuk mengatasi hambatan dalam menanamkan sifat sabar pada anak usia dini di RA Persis I ?

Sesuai dengan rumusan masalah di atas, maka tujuan penelitian ini adalah sebagai berikut:

1) Untuk mengetahui informasi mengenai upaya guru dalam menanamkan sifat sabar pada anak usia dini di RA Persis I

2) Untuk mengetahui hambatan bagi peran guru dalam menanamkan sifat sabar pada anak usia dini di RA Persis I

3) Untuk mengetahui solusi guru terhadap hambatan dalam menanamkan sifat sabar pada anak usia dini di RA Persis I

\section{METODE PENELITIAN}

Desain penelitian yang digunakan dalam penelitian ini adalah metode studi kasus dengan menggunakan pendekatan kualitatif. Arikunto (2006, hlm. 142) mengungkapkan bahwa, "Studi kasus adalah penelitian yang dilakukan secara intensif, rinci dan mendalam terhadap suatu organisasi lembaga atau gejala tertentu".

Metode penelitian studi kasus dengan pendekatan kualitatif ini dipilih karena menganggap metode dan pendekatan ini sangat cocok dengan fokus masalah yang peneliti ambil, yaitu mengenai upaya guru dalam menanamkan sifat sabar pada anak usia dini. Selain itu, alasan digunakannya studi kasus adalah untuk mengetahui secara lebih mendalam kejadian yang ada di lapangan mengenai bagaimana upaya guru dalam menanamkan sifat sabar pada anak usia dini di RA Persis I.

Penelitian ini mengambil partisipan dua guru kelas dan seorang kepala sekolah yang berada di RA Persis I yang beralamatkan di Jl. KH. Wahid Hasyim Gg. H. Saidin No. 482/198A Kota Bandung.

Instrumen yang digunakan dalam penelitian ini dikembangkan dari rumusan masalah dan tujuan penelitian yang disusun oleh peneliti sendiri mengenai upaya guru dalam sifat sabar pada anak usia dini.

Agar tidak menimbulkan kesalahpahaman terhadap penelitian yang akan dilakukan dan untuk memperjelas penelitian ini, maka ada istilah yang akan dijelaskan yaitu upaya guru dalam menanamkan sifat sabar yang dimaksudkan dalam penelitian ini adalah bentuk usaha yang dilakukan oleh guru yang mengajar di sekolah RA Persis I ini, diantaranya seperti menahan diri agar tidak mudah marah, sabar mengantri, sabar menunggu giliran, tidak merebut mainan temannya, tidak tergesa-gesa dalam melakukan sesuatu dan melatih diri dalam ketaatan sejak usia dini agar selalu berbuat kebaikan, misalnya saling memaafkan.

Miles and Huberman
Sugiyono, 2012, hlm.
mengungkapkan bahwa aktivitas dalam
analisis data kualitatif dilakukan secara
interaktif dan berlangsung secara terus
menerus sampai tuntas, sehingga datanya
sudah jenuh. Aktivitas dalam analisis
data yaitu, data reduction, data display,
dan conclusion drawing/verivication
(Sugiyono 2012, hlm. 91). 
Selain itu, penelitian ini mengadakan member check. Member check adalah proses pengecekan data yang diperoleh peneliti kepada pemberi data. Hal ini bertujuan agar informasi yang diperoleh sesuai dengan apa yang dimaksud sumber data atau imforman (Sugiyono, 2017, hlm. 193) .

\section{HASIL PENELITIAN DAN PEMBAHASAN}

\section{Upaya Guru Dalam Menanamkan Sifat Sabar Pada Anak Usia Dini}

\begin{abstract}
Berdasarkan hasil wawancara terhadap beberapa informan dapat disimpulkan bahwa penanamanan akhlakul karimah itu sangat penting ditanamkan pada anak usia dini karena ciri anak usia dini itu disebut dengan the golden age atau masa keemasan. Hal ini sejalan dengan Mursid (2010, hlm. 2) mengungkapkan bahwa anak usia dini merupakan periode awal yang paling penting dan mendasar (fundamental) sepanjang rentang pertumbuhan dan perkembangan kehidupan manusia sampai dengan periode akhir perkembangannya. Oleh karena itu perlu adanya pendidikan dan pengajaran sebagai alat pengembangan potensi spiritual anak. Selain itu, perlunya kerjasama dengan orangtua agar apa yang ditanamkan di sekolah, diteruskan di rumahnya.
\end{abstract}

Penanaman akhlakul karimah sejak usia dini akan membantu anak untuk dapat bersosialisasi dengan lingkungannya, baik dalam keluarga, sekolah, maupun masyarakat. Hal ini dilakukan supaya anak terbiasa berperilaku yang mencerminkan nilainilai agama. Anak-anak harus terbiasa menghormati orangtuanya sendiri, menghormati tamu, menghormati guru, bersopan santun kepada teman, dan tetangga serta sudah terbiasa pula menyayangi yang lebih muda. Diingatkan oleh baginda Rasulullah SAW bahwa, penanaman akhlak sejak usia dini memiliki makna yang sangat penting. Dan pada periode ini kepekaan anak terhadap lingkungan sangat tajam, maka yang ia ambil dari lingkungan dan terbiasa melakukannya akan sulit dihilangkan pada usia-usia berikutnya (Halim, 2003: 188)

Sabar adalah bentuk menahan diri dari segala cobaan yang dihadapinya. Bukan hanya pada saat seseorang ditimpa musibah, melainkan ketika ia mendapat nikmat dari Allah dan selalu berprasangka baik kepada Allah dan tidak pernah mengeluh serta selalu bersyukur terhadap apa yang telah ditimpakan kepada hambanya, dengan tujuan mengharapkan ridha-Nya untuk kebahagiaan dunia dan akhirat. Anakanak harus mulai diajarkan untuk bersabar sejak usia dini dan guru dapat mengajarkan anak untuk bersabar melalui kegiatan atau aktivitas sehari-hari anak.

Sifat sabar akan membuat manusia hidup dengan penuh ketenangan dan selalu bersyukur atas apa yang ditimpakannya. Hal ini tentu baik untuk ditanamkan pada anak sejak usia dini. Dengan cara melatih anak membiasakan hal-hal yang baik, bertingkah laku sopan baik dalam perilaku keseharian maupun dalam bertutur kata (Mansur, 2009, hlm. 325). Untuk itu guru harus memberikan contoh yang baik kepada anak didiknya. Melalui contoh yang ditunjukkan kepada anak, maka anak akan melihat dan mencontoh apa yang dilakukan oleh gurunya. Anak akan tumbuh dengan baik dan berakhlak mulia seperti tokoh panutannya (Helmawati, 2016: 31)

Berdasarkan hasil data wawancara dan observasi diperoleh data mengenai sifat sabar di sekolah RA Persis I ini 
diantaranya yaitu sabar mengantri dan sabar menunggu giliran.

\section{Hambatan Yang Dihadapi Guru Dalam Menanamkan Sifat Sabar Pada Anak Usia Din}

Berdasarkan hasil data wawancara Ibu. Lala dapat disimpulkan bahwa hambatan yang dihadapi guru di sekolah RA Persis I ini yaitu hambatannya masih dapat diatasi dikarenakan kondisi anak yang masih stabil, dalam artian emosinya tidak berlebihan. Hal ini sejalan dengan Ibu Iin yang mengungkapkan bahwa hambatan yang dihadapi guru tidak ada, dan beliau menambahkan bahwa dalam menanamkan sifat sabar pada anak harus pada diri sendiri terlebih dahulu yaitu dari gurunya dalam memberikan tauladan yang baik.

Namun dalam penelitian ini ditemukan 2 kasus anak di kelas B yang memiliki emosi yang belum stabil seperti belum bisa menerima masukan dari orang lain, apabila berbaris untuk cuci tangan selalu ingin di depan, dan apabila kuisnya di jawab orang lain menangis. Sedangkan anak yang lain sudah bisa menerima masukan dari orang lain dan sudah dapat mengendalikan emosinya.

\section{Cara Pencegahan serta Solusi untuk Anak yang Tidak Bisa Bersabar}

Pencegahan merupakan sebuah tindakan ketika dalam proses pekerjaan terjadi masalah. Begitu juga dalam pembelajaran pasti akan ada permasalahan yang timbul dan salah satu masalah yang ingin peneliti angkat salah satunya tentang sabar. Menurut Fathurrohman dkk, (2013: 1), institusi pendidikan yang terdiri dari sekolah dan/atau madrasah, keluarga, dan lingkungan masyarakat harus menjadi teladan bagi proses pembelajaran peserta didik.
Untuk menerima emosi negatif anak tersebut, guru melakukan beberapa cara untuk mengatasi anak tersebut diantaranya yaitu memeluk anak, memberikan pengertian, dan mengenal karakter anak

\section{SIMPULAN, IMPLIKASI DAN REKOMENDASI}

\section{A. SIMPULAN}

Berdasarkan hasil penelitian dan pembahasan diperoleh beberapa simpulan sebagai berikut :

\section{Upaya Pihak Sekolah dan Guru Dalam Menanamkan Sifat Sabar Pada Anak Usia Dini

$$
\text { Berdasarkan hasil }
$$

wawancara dan observasi yang telah dilakukan, kedua belah pihak memiliki pandangan yang hampir sama; "Bahwa akhlak merupakan sifat yang tertanam dalam jiwa sebagai hasil dari proses pendidikan, yang dalam melakukannya berlangsung secara spontan (tanpa melalui pertimbangan) terlebih dahulu dan hal itu membutuhkan program disekolah sebagai penanaman akhlak. Meski dasar akhlak itu akan kembali lagi dirumah. Menanamkan akhlakul karimah dalam pelaksanaannya dapat menggunakan metode keteladanan, pembiasaan, nasihat, dan cerita. Adapun bentuk-bentuk perilaku akhlakul karimah yang dapat diajarkan diantaranya yaitu mengucapkan salam, meminta maaf jika melakukan kesalahan, mengaji iqro, membaca do'a sehari-hari, membaca surat-surat pendek, membaca mahfudzat, praktek wudhu dan praktek shalat. Adapun yang ditemukan mengenai sabar ini diantaranya sabar mengantri dan sabar menunggu giliran. 
4. Hambatan Yang Dihadapi Guru Dalam Menanamkan Sifat Sabar Pada Anak Usia Dini

Berdasarkan hasil wawancara mengenai hambatan yang dihadapi guru dalam menanamkan sifat sabar pada anak dapat disimpulkan bahwa dalam penelitian ini ditemukan 2 kasus anak di kelas B yang memiliki emosi yang belum stabil seperti belum bisa menerima masukan dari orang lain, apabila berbaris untuk cuci tangan selalu ingin di depan, dan apabila kuisnya di jawab orang lain menangis. Sedangkan anak yang lain sudah bisa menerima masukan dari orang lain dan sudah dapat mengendalikan emosinya.

\section{Cara Pencegahan Serta Solusi Untuk Anak Yang Tidak Bisa Bersabar}

Berdasarkan kajian peneliti setelah mengkaji teks wawancara dan observasi, maka peneliti dapat menyimpulkan bahwa kaitan dengan kesabaran seseorang tergantung bagaimana pembiasaan dari lingkungan sekolah dan rumah. Karena terlihat jelas ketika dilapangan ada yang tenang-tenang saja, ada yang iseng dan lain-lain.Peran guru paling dominan ketika disekolahan namun aktivitas di luar sekolah, orang tua yang lebih tahu karakter anaknya. Adapun cara pencegahan serta solusi untuk anak yang tidak bisa bersabar yaitu dengan cara memeluk anak, memberikan pengertian, dan mengenal karakter anak.

\section{IMPLIKASI}

Adapun implikasi dari penelitian ini diantaranya yaitu sebagai berikut:

\section{Bagi Peneliti}

Temuan penelitian ini dapat memberikan gambaran mengenai upaya guru dalam menanamkan akhlakul karimah pada anak usia dini pada, terutama pada aspek sifat sabar di RA Persis I

\section{Bagi Lembaga/Sekolah}

Temuan penelitian ini dapat memberikan implikasi dalam menanamkan akhlakul karimah pada anak yang lebih terarah dan terstruktur

\section{B. REKOMENDASI}

$$
\text { Berdasarkan hasil }
$$

kesimpulan di atas, penulis memberikan saran demi perbaikan dan juga untuk memberikan gambaran kepada semua pihak terkait hubungan antara supervisi akademik kepala TK dengan kompetensi guru TK di Kecamatan Coblong Kota Bandung. Adapun rekomendasi tersebut yaitu:

1. Bagi Lembaga/Sekolah

Lembaga pendidikan dalam hal ini adalah sekolah pendidikan anak usia dini, sekolah harus membuat program yang dapat lebih dekat dengan para orang tua agar dapat menyeimbangkan program disekolah dengan diluar sekolah, minimal anak tidak sampai terlalu bebas bergaul dengan teman-teman diluar tapi orang tua harus selektif.

2. Bagi Peneliti Selanjutnya

Penelitian ini membahasa tentang upaya guru dalam menanamkan sifat sabar. Penelitian ini diharapkan dapat menjadi salah satu sumber dan referensi baru bagi para peneliti selanjutnya. Adapun penelitian ini masih dalam ruang lingkup terbatas, sehingga masih banyak aspek lain yang belum terungkap. Maka dalam hal ini peneliti berharap kepada peneliti lainnya untuk meneliti lebih lanjut dengan mengungkap permasalahan yang sama, akan tetapi dengan adanya subjek dan 


variabel yang lebih
dikembangkan,
memberikan sumbangan ilmu
kepada mahasiswa maupun
pengajar.

\section{DAFTAR PUSTAKA}

Arikunto, S. (2006). Metode Penelitian Kualitatif. Jakarta: Bumi Aksara.

Danim, S. (2011). Pengantar Pendidikan. Bandung : ALFABETA.

Fachruddin, H. S. (1985). Membentuk Moral "Bimbingan Al-Qur'an". Jakarta: Bina Aksara.

Fathurrohman, Pupuh. dkk. (2013). Pengembangan Pendidikan Karakter. Bandung: Refika Aditama.

Hainstock, Elizabeth G. (1999). Metode Pengajaran Montessori Untuk Anak Prasekolah. Jakarta: Pustaka Delapratasa.

Halim, M. Nipan Abdul. (2003). Anak Saleh Dambaan Keluarga. Yogyakarta: Mitra Putsaka.

Helmawati. (2016). Pendidik Sebagai Model. Bandung: PT Remaja Rosadakarya.

Mansur, M. A. (2009). Pendidikan Anak Usia Dini Dalam Islam. Yogyakarta: Pustaka Pelajar.

Mursid. (2010). Manajemen Lembaga Pendidikan Anak Usia Dini (PAUD). Semarang: AKFI Media.

Sari, F. R. (2010). Perananan Guru Dalam Membimbing Moral Naka Usia Dini di TK Aisyiyah Bustanul Athfal (ABA) Sapen Yogyakarta. (Skripsi), PAUD.

Sugiyono. (2012). Metode Penelitian Kuantitatif, Kualitatif dan $R \& D$. Bandung: Alfabeta

Syaodih, Ernawulan. (t.t). Psikologi perkembangan. Fakultas Ilmu Pendidikan Universitas Pendidikan Indonesia. 